\title{
PENERAPAN ALGORITMA EVOLVING NEURAL NETWORK UNTUK PREDIKSI CURAH HUJAN
}

\author{
Subhan Panji Cipta \\ Jurusan Teknik Informatika, STMIK Indonesia Banjarmasin \\ e-mail: Panji.cipta@gmail.com
}

\begin{abstract}
ABSTRAK
Informasi iklim dan cuaca telah memberikan kontribusi sebagai salah satu pertimbangan bagi para pengambil keputusan. Hal ini muncul karena informasi cuaca / iklim memiliki nilai ekonomi dalam berbagai kegiatan, mulai dari pertanian ke pengendali banjir. Dari data yang diperoleh tersirat bahwa prediksi curah hujan saat ini tidak begitu akurat. Prakiraan sering diberikan ke publik secara teratur adalah ramalan cuaca, bukan jumlah curah hujan. Penelitian ini menggunakan algoritma Evolving Neural Network (ENN) sebagai pendekatan untuk memprediksi curah hujan. Pengolahan data dan perhitungan akan menggunakan MatLab 2009b. Parameter yang digunakan dalam penelitian ini adalah waktu, curah hujan, kelembaban dan suhu. Hasil penelitian juga dibandingkan dengan hasil tes dan prediksi BPNN BMKG. Dari hasil penelitian yang dilakukan dari tahap awal untuk menguji dan pengukuran, hasil dari ENN ini memiliki prediksi curah hujan dengan akurasi yang lebih baik daripada BPNN dan prediksi algoritma $B M K G$.
\end{abstract}

Kata kunci: Prediksi, curah hujan, berkembang jaringan saraf.

\begin{abstract}
Weather and climate information have contributed as one consideration for decision makers. This arises because the information the weather / climate has economic value in a variety of activities, ranging from agriculture to flood control. From the data obtained implied that the current rainfall prediction not so accurate. Forecasts are often given to the public on a regular basis is the weather forecast, not the amount of rainfall. This study uses an algorithm Evolving Neural Network (ENN) as an approach to predict the rainfall, the data processing and calculations will use MatLab 2009b. The parameters used in this study is time, rainfall, humidity and temperature. The results also compared with the test results and predictions BPNN $B M K G$. From the results of research conducted from early stage to test and measurement, the application of this ENN has a rainfall prediction with accuracy better than the BPNN and prediction algorithms $B M K G$.
\end{abstract}

Keywords : Prediction, rainfall, evolving neural network.

\section{PENDAHULUAN}

Informasi cuaca dan iklim mempunyai andil sebagai salah satu bahan pertimbangan bagi pembuat keputusan. Oleh karena itu, sangat bijaksana apabila informasi cuaca dan iklim diperhatikan dan digunakan sebagai salah satu bahan pertimbangan untuk mengambil keputusan, baik pada waktu sebelum maupun selama melakukan kegiatan. Hal ini muncul karena informasi cuaca/ iklim mempunyai nilai ekonomi dalam berbagai kegiatan, mulai dari pertanian sampai dengan pengendalian banjir. Selain itu, informasi cuaca/ iklim mempunyai peran dalam memantau anomali/ perubahan iklim secara global sebagai dampak peningkatan aktivitas manusia [1]. Data curah hujan biasanya tercatat secara harian. Zhi-liang Wang dan Hui-hua Sheng [2] mengusulkan penerapan General Regression Neural Network (GRNN) untuk memprediksi curah hujan tahunan di Zhengzhou. Mereka membuktikan bahwa GRNN memiliki kelebihan ketika prosesfitting danprediksi dibandingkan dengan Backpropagation Neural Network (BP-NN) dan metode stepwise regression analysis (SRA). Hasil simulasi GRNN untuk curah hujan tahunan lebih baik dengan akurasi yang lebih tinggi daripada BP-NN.Pei-Chann Chang and Yen-Wen Wang [3] menggunakan Evolving Neural Network untuk memprediksi produksi PCB dengan hasil yang baik.

Dengan demikian, salah satu pendekatan untuk menetapkan nilai bobot pada neural network adalah algoritma genetika, yang selain Pei-Chann Chang and Yen-Wen Wang [3], juga telah diterapkan oleh Li Chungui, Xu Shu'an, dan Wen Xin [4] untuk prediksi arus lalu lintas. Ganji Huang dan Lingzhi Wang [5] melatih Neural network untuk peramalan hidrologi. Ketiga penelitian tersebut mengusulkanneural network yang berevolusi. Model ini menyerap beberapa manfaat dari algoritma genetika dan neural network. Hasil perbandingan menunjukkan bahwa model yang disarankan dapat meningkatkan akurasi prediksi.

Rumusan masalah dari penelitian ini adalah:

Akurasi prediksi curah hujan saat ini belum begitu akurat, sehingga perlu pendekatan yang dapat menghasilkan presiksi curah hujan yang lebih akurat.Karena itu penelitian ini akan menggunakan algoritma Evolving Neural Network (ENN) sebagai pendekatan untuk memprediksi curah hujan. Sehinggga Question Research: "Bagaimana penerapan algoritma Evolving Neural Network untuk memprediksi curah hujan dengan lebih akurat.

Tujuan penelitian ini adalah: 
Berdasarkan latar belakang dan rumusan masalah diatas, maka penelitian ini bertujuan untuk menerapkan algoritma Evolving Neural Network (ENN) untuk memprediksi curah hujan dengan lebih akurat .

Manfaat dari penelitian ini adalah:

a. Bagi Penulis

Menerapkan dan menggunakan teori yang didapat dibangku kuliah terutama yang berhubungan dengan algoritma Evolving Neural Network (ENN).

b. Bagi Instansi

Hasil penelitian ini diharapkan mampu menjadi alat prediksi curah hujan BMKG khususnya Stasiun Klimatologi Banjarbaru, Kalimantan Selatan.

c. Bagi Pembaca

Dapat memberikan gambaran dan pemahaman tentang bagaimana penerapan algoritma Evolving Neural Network (ENN) dalam studi kasus data rentet waktu curah hujan.

\section{TINJAUAN PUSTAKA}

\section{A.Hujan, Curah Hujan, Cuaca dan Iklim}

Hujan merupakan salah satu bentuk presipitasi uap air yang berasal dari awan yang terdapat di atmosfer. Bentuk presipitasi lainnya adalah salju dan es. Untuk dapat terjadinya hujan diperlukan titik-titik kondensasi, amoniak, debu dan asam belerang. Titik-titik kondensasi ini mempunyai sifat dapat mengambil uap air dari udara [1].

Curah Hujan $(\mathrm{CH})$ adalah jumlah air yang jatuh di permukaan tanah datar selama periode tertentu yang diukur dengan satuan tinggi (mm) di atas permukaan horizontal bila tidak terjadi evaporasi, runoff dan infiltrasi. Satuan $\mathrm{CH}$ adalah mm, inch [1].

Cuaca adalah keadaan variable atmosfer secara keseluruhan disuatu tempat dalam selang waktu yang pendek. Sedang secara fungsi komponen, cuaca adalah keadaan atmosfer yang dinyatakan dengan nilai berbagai parameter, antara lain suhu, tekanan, angin, kelembaban dan berbagai fenomena hujan, disuatu tempat atau wilayah selama kurun waktu yang pendek.

Iklim adalah sintesis kejadian cuaca selama kurun waktu yang panjang, yang secara statistik cukup dapat dipakai untuk menunjukkan nilai statistik yang berbeda dengan keadaan pada setiap saatnya. Dapat juga dinyatakan sebagai konsep abstrak yang menyatakan kebiasaan cuaca dan unsur-unsur atmosfer disuatu daerah selama kurun waktu yang panjang [6].

\section{B.Data Mining}

Data mining didefinisikan sebagai proses menemukan pola dalam data. Proses itu harus otomatis atau semi otomatis. Pola yang ditemukan harus berguna sehingga dapat memberikan keuntungan [7]. Data mining adalah proses menemukan hubungan yang bermakna, pola dan tren dengan memilah-milah sejumlah besar data dengan menggunakan teknologi pengenalan pola serta statistik dan teknik matematika [8].

\section{C.Neural Network}

Jaringan saraf tiruan adalah sebuah alat penting untuk pemodelan kuantitif. Jaringan saraf tiruan sangat populer digunakan di antara para peneliti dan praktisi selama 20 tahun terakhir dan telah berhasil diterapkan untuk memecahkan suatu varietas masalah di hampir semua bidang bisnis, industri, dan ilmu pengetahuan (Widrow, Rumelhart \& Lehr, 1994). Saat ini, jaringan saraf tiruan diperlakukan sebagai standar alat data mining dan digunakan untuk tugas-tugas data mining seperti mengklasifikasikan pola, analisis data rentet waktu, prediksi, dan clustering [9].

\section{Evolving Neural Networks (ENN)}

Evolving Neural Network adalah sebuah cara pembobotan antar neuron pada layer berbeda dengan menggunakan prinsip algoritma genetika (GA). Gambar berikut menjelaskan struktur algoritma ENN [10]: 


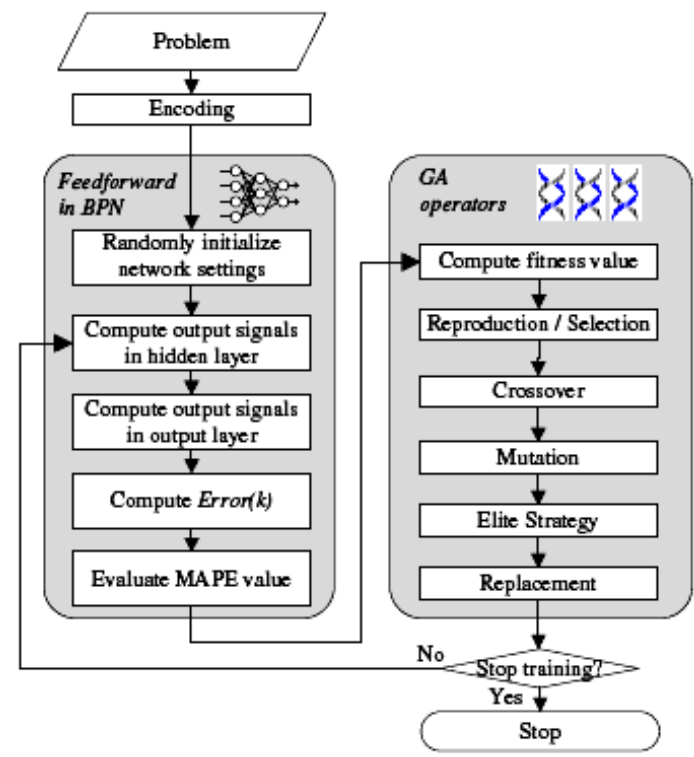

Gambar. 1. Struktur Algoritma Evolving Neural Network

Proses algoritma ENN [3] [11] [12]:

1. Encoding Represantasi Kromosom (encoding)

Setiap gen mempresentasikan bobot antara dua neuron di layer berbeda. Sebuah kromoson dibangun dari rangkaian gen yang diilustrasikan dalam gambar 1 .

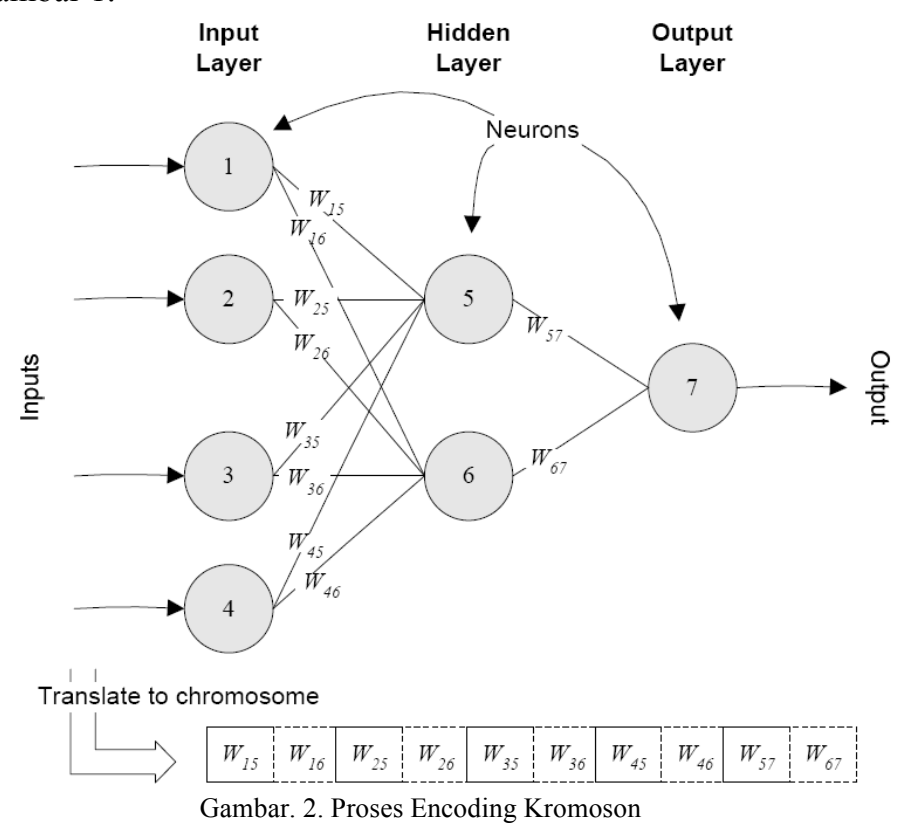

Contoh, Gen pertama dalam untaian kromoson adalah W15, yaitu bobot yang menghubungkan neuron 1 dan neuron 5 . Gen kedua adalah W16, yaitu bobot penghubung neuron 1 dan 6. Demikian seterusnya.

2. Menentukan populasi awal dari kromosom (Initial Population)

Bobot awal ditentukan acak dari 0 sampai 1. Bobot dalam kromosom akan dievaluasi oleh operator GA.

3. Menghitung nilai objektif setiap kromosom. (FF-NN)

Mean Absolute Percentage Error (MAPE) digunakan sebagai fungsi untuk mengevaluasi simpangan data traning selama proses training.

(1) Menghitung output dari hidden layer

(2) Menghitung output dari output layer

(3) Menghitung error

(4) Evaluasi nilai MAPE dari g(s)

4. Menghitung fungsi fitness. (Compute fitness value)

Suatu individu dievaluasi berdasarkan suatu fungsi tertentu sebagai ukuran nilai kualitasnya. Fungsi ini disebut fungsi fitness.

fit(s) $=1-g(s)$ 
5. Seleksi orang tua (Reproduction/Selection)

Kemungkinan $\mathrm{p}(\mathrm{s})$ dari setiap kromosom $\mathrm{s}$ terpilih sebagai orang tua didefinisikan:

6. Mutasi Silang (Crossover)

$$
p(s)=\frac{f i t(s)}{\sum f i t(s)}
$$

GA menjalankan oprator mutasi silang terhadap pasangan orang tua berdasarkan probabilitas tertentu. Operasi yang dilakukan adalah operasi 2 titik (2-point crossover)

7. Mutasi (Mutation)

Operator GA menjalankan mutasi pada setiap kromosom. Operasi yang adalah mutasi 1 titik (1-point mutation) untuk mendapakan solusi yang optimal.

8. Strategi Elite (Elite Strategy)

Operasi yang dilakukan adalh memilih 50\% solusi teratas berurutan untuk mempertahankan kualitas solusi yang ada pada setiap generasi. Dengan kata lain, perlu peng-kopi-an individu terbaik pada suatu generasi untuk dimasukkan sebagai anggota populasi generasi berikutnya. Sehingga populasi baru memiliki minimal satu individu terbaik yang kualitasnya sama atau lebih baik dibandingkan dengan generasi sebelumnya.

9. Seleksi (Replacement)

Populasi baru yang dihasilkan dari proses sebelumnya menggantikan seleuruh populasi generasi lama.

10. Kriteria penghentian (Stopping Criteria)

Jika jumlah generasi telah sama dengan nilai maksimumnya, maka proses akan berhenti. Jika belum, proses kembali ke langkah 3.

11. Prediksi (Forecast and Recall)

Fungsi MAPE digunakan untuk mengevaluasi akurasi dari setiap prediksi yang dihasilkan ENN.

\section{METODE PENELITIAN}

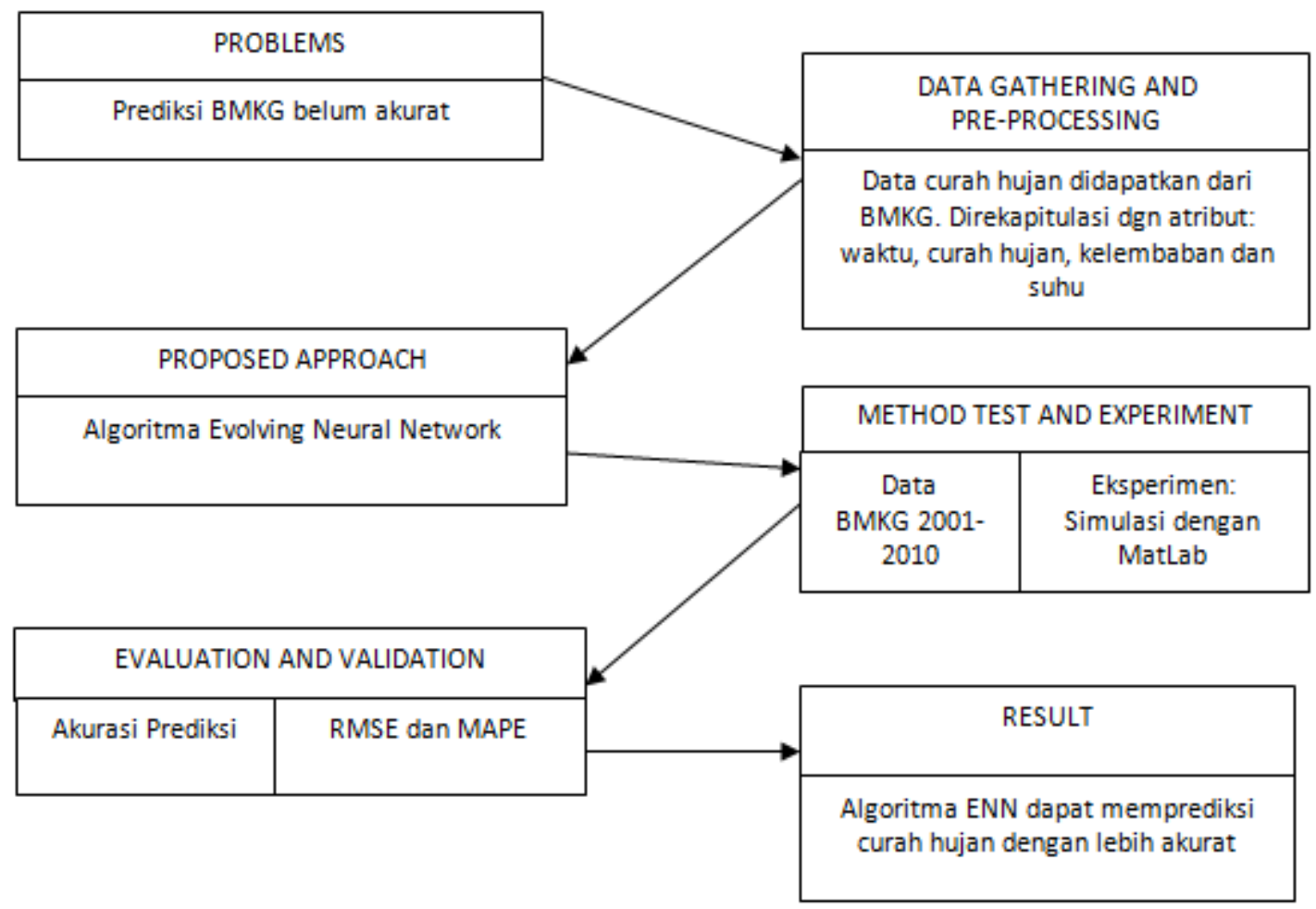

Gambar. 3. Tahapan Metode Penelitian Eksperimen

\section{A. Metode Pengumpulan data}

Penelitian ini memakai data curah hujan dan kelembaban yang didapatkan dari BMKG - Stasiun Klimatologi Banjarbaru, Kalimantan Selatan. Data yang dibutuhkan dalam penelitian ini adalah data sekunder dan data primer.

\section{B. Metode Pengolahan Data Awal}

Data yang didapatkan dari instasi terkait masih berupa data yang terdiri dari berbagai parameter, sehingga harus direkapitulasi terlebih dahulu. Rekapitulasi tersebut dilakukan dengan memperhatikan kebutuhan. Data hasil proses ini adalah data 
dengan atribut: Waktu, Curah hujan, Kelembaban dan Suhu. Tiap baris data adalah data setiap bulan selama 10 tahun, sehingga tersedia 120 baris data.

TABEL.1.

DATA REKAPITULASI TAHUN 2001-2010

\begin{tabular}{ccccc}
\hline Tahun & Bulan & Hujan & lembab & suhu \\
\hline \multirow{2}{*}{2001} & Jan-01 & 354,6 & 90,0 & 26,23 \\
& Feb-01 & 145,2 & 89 & 26,63 \\
& Mar-01 & 234,2 & 89 & 26,81 \\
& Apr-01 & 206,8 & 89 & 27 \\
$\ldots$ & $\ldots$ & $\ldots$ & $\ldots$ & $\ldots$ \\
& Sep-10 & 338,2 & 88,92 & 25,94 \\
& Okt-10 & 256,5 & 86,01 & 26,65 \\
& Nop-10 & 317,5 & 87,56 & 26,46 \\
\end{tabular}

\section{Metode Yang Diusulkan}

Berdasarkan related research pada bab sebelumnya, nilai akurasi prediksi data rentet waktu menggunakan metode Evolving Neural Network (ENN) dinyatakan lebih akurat sehingga metode yang diusulkanuntuk memprediksi curah hujan adalah Evolving Neural Network (ENN) dan akan diimplementasikan dengan menggunakan MatLab 2009b.

\section{Neural Network Backpropagation (BPNN)}

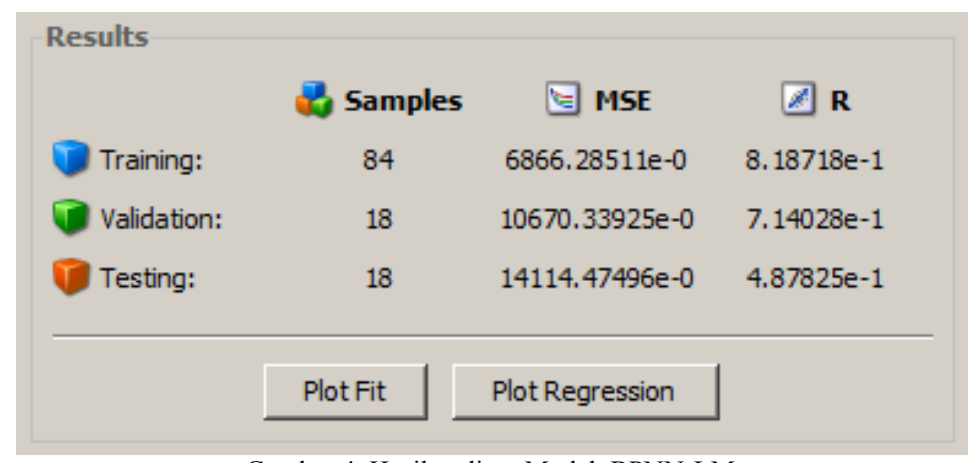

Gambar.4. Hasil coding Matlab BPNN-LM

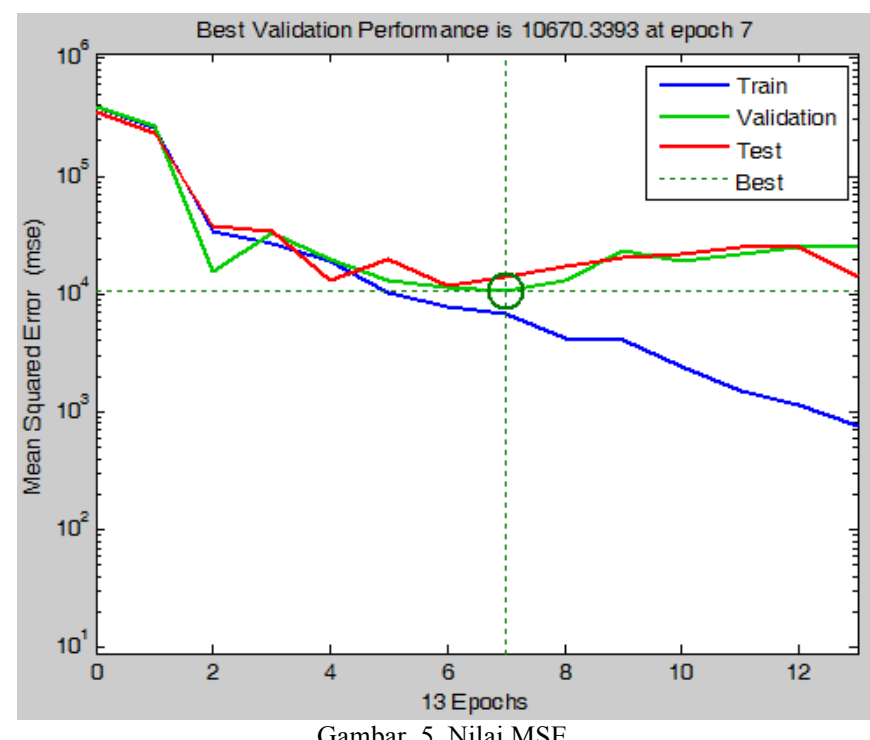

\section{E.Model Evolving Neural Network (ENN)}

Lima parameter penting algoritma genetika [12], yaitu: tipe crossover dan nilainya, tipe mutasi dan nilainya serta tipe seleksi, diatur menggunakan desain eksperimen Taguchi [3]. Desain eksperimen Taguchi digunakan untuk pengaturan parameter 
parameter itu. Pendekatan dilakukan dengan perhitungan Signal-to-Noise (S/N), untuk mendapatkan kombinasi yang lebih baik. S/N didefinisikan [13]:

Di mana:

$$
S / N=-10 \times \log \left(\frac{1}{n} \times \sum_{i=1}^{n} y_{i}^{2}\right)
$$

$\mathrm{n}=$ banyaknya eksperimen (baris data)

$\mathrm{y}_{\mathrm{i}}=$ hasil eksperimen ke-i

Kode dan level untuk masing-masing parameter tersebut:

TABEL II

DATA REKAPITULASI TAHUN 2001-2010

\begin{tabular}{lllll}
\hline \multicolumn{4}{c}{ DATA REKAPITULASI TAHUN 2001-2010 } & Level 4 \\
\hline Cross over (A) & Level 1 & Level 2 & Level 3 & 2-Point \\
Mutasi (B) & 1-Point & 1-Point & 2-Point & Shift \\
Seleksi (C) & 1-Point & 1-Point & Shift & Elite \\
Nilai Cross over (D) & Total & Total & Elite & 0,8 \\
Nilai Mutasi (E) & 0,2 & 0,4 & 0,6 & 0,7 \\
\hline
\end{tabular}

Menurut Pei-Chann Chang dkk [14], profil konvergensi untuk data time-series semi musiman menunjukkan bahwa sistem dapat bertemu setelah 2.000 generasi bahkan untuk ukuran populasi yang kecil misalnya 10. Namun, untuk ukuran populasi konvergensi cepat dan halus didapatkan pada populasi 40 atau 50, yang konvergen ke kondisi cukup stabil setelah sekitar 300 generasi.

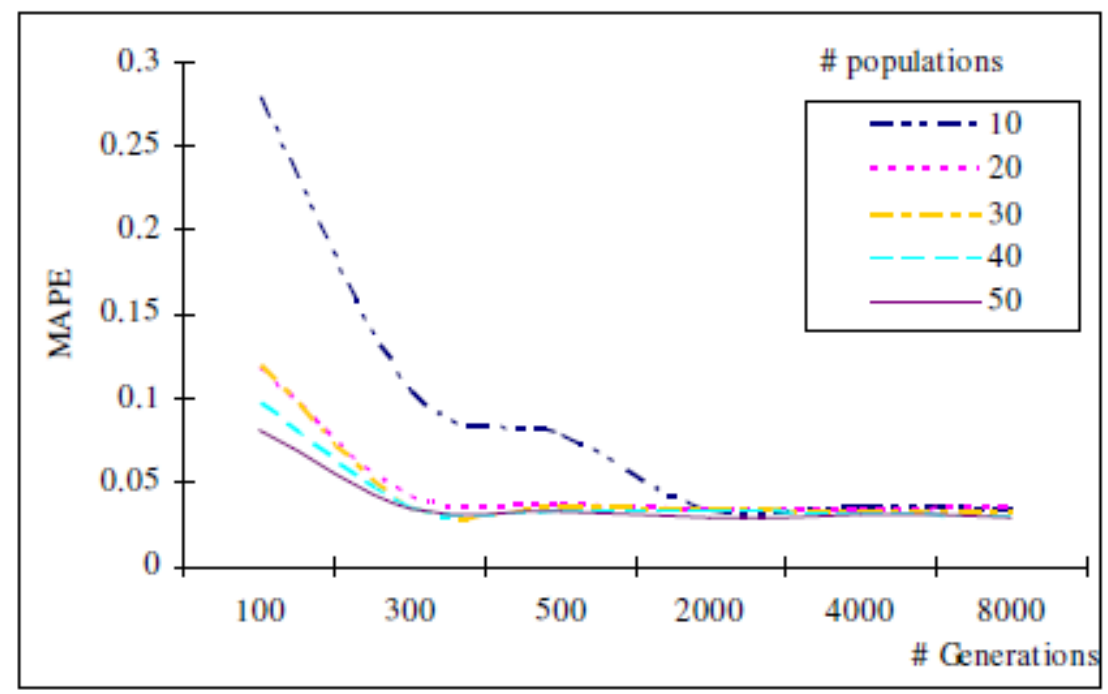

Gambar. 6. Nilai MAPE

Oleh karena itu, dalam pengujian akan digunakan ukuran populasi 50 sebagai populasi awal untuk percobaan.

Dengan data curah hujan sebagai input dan target, dilakukan tiga kali percobaan algoritma genetika (tanpa neural network) dengan populasi 50, dan parameter masing-masing operator di-setting sesuai level rencana, kemudian menghitung rata-rata $\mathrm{S} / \mathrm{N}$ rasio dari setiap tingkat faktor, hasilnya ditunjukkan pada tabel berikut:

TABEL III

RATA-RATA S/N RASIO

\begin{tabular}{rlllll}
\hline Faktor & $\mathrm{A}$ & $\mathrm{B}$ & $\mathrm{C}$ & $\mathrm{D}$ & $\mathrm{E}$ \\
\hline Level 1 & 12,19 & $\mathbf{2 4 , 0 0}$ & 12,15 & 14,31 & 14,79 \\
Level 2 & 12,98 & 23,47 & 13,02 & 14,40 & $\mathbf{1 5 , 1 4}$ \\
Level 3 & $\mathbf{1 7 , 6 0}$ & 5,91 & 11,78 & 14,96 & 14,36 \\
Level 4 & 16,51 & 5,91 & $\mathbf{1 6 , 9 9}$ & $\mathbf{1 5 , 6 2}$ & 15,05 \\
\hline
\end{tabular}

Dari tabel ini, kombinasi terbaik dari pengaturan parameter dapat ditemukan sebagai (A) 3 - (B) 1 - (C) 4 - (D) 4 - (E) 2 (sebagaimana disorot dalam huruf tebal). Kode-kode ini mewakili dua titik crossover, satu mutasi titik, penggantian strategi elitis, Crossover rate $=0,8$, dan tingkat mutasi $=0,3$. 


\section{F. Hasil Eksperimen}

TABEL IV

EVALUASI TIAP STRUKTUR

\begin{tabular}{lllllll}
\hline & Arsitektur FFN & \multicolumn{4}{c}{ Evaluasi } \\
\hline Input & Hidden-1 & Out & MSE & RMSE & MAPE & MAD \\
$\mathbf{4}$ & $\mathbf{2}$ & $\mathbf{1}$ & 7621,414 & 87,301 & $29,07 \%$ & 74,592 \\
$\mathbf{4}$ & $\mathbf{4}$ & $\mathbf{1}$ & 3913,691 & 62,560 & $29,76 \%$ & 84,717 \\
$\mathbf{4}$ & $\mathbf{2}$ & $\mathbf{1}$ & 2528,506 & 50,284 & $15,15 \%$ & 43,317 \\
$\mathbf{4}$ & $\mathbf{4}$ & $\mathbf{1}$ & 1032,203 & 32,128 & $19,10 \%$ & 57,020 \\
\hline
\end{tabular}

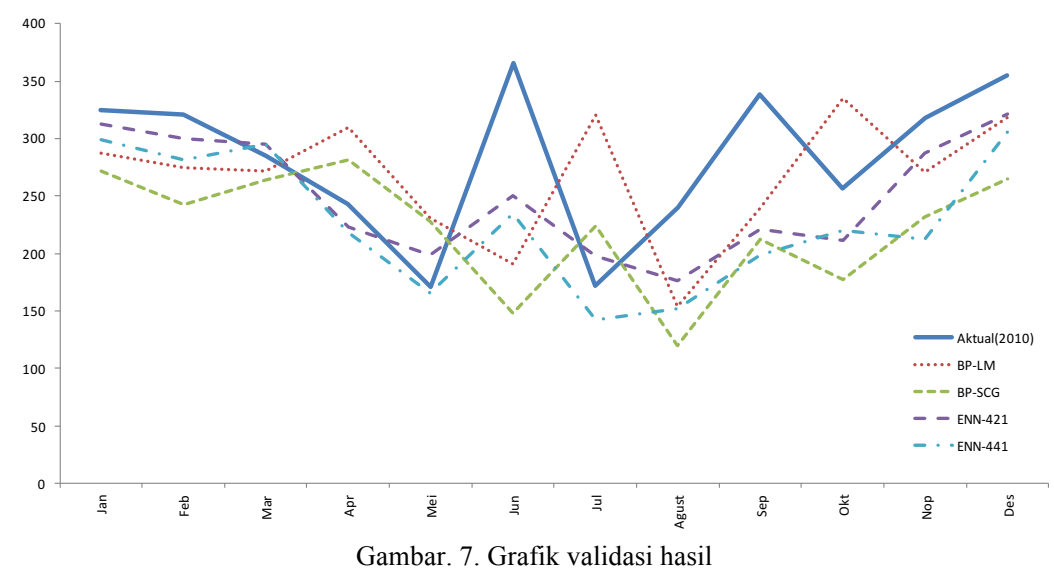

Terlihat bahwa nilai MSE, RMSE, MAPE dan MAD yang dihasilkan oleh ENN jauh lebih kecil daripada BPNN. Dengan demikian, maka dapat disimpulkan bahwa algoritma Envolving Neural Network memprediksi curah hujan lebih akurat dari pada BPNN-Levenberg-Marquardt dan BPNN-scaled conjugate gradient serta prediksi BMKG, dengan tingkat keakuratan prediksi sebesar $85 \%$.

\section{KESIMPULAN DAN SARAN}

\section{A. Kesimpulan}

Dari hasil penelitian yang dilakukan dari tahap awal hingga pengujian, dan pengukuran, penerapan ENN ini memiliki prediksi curah hujan dengan tingkat akurasi yang lebih baik dibandingkan dengan algoritma BPNN dan prediksi BMKG.

Dengan demikian, adanya penerapan algoritma ENN mampu memberikan solusi bagi petugas maupun petani, serta mampu menjadi alat prediksi curah hujan yang dapat digunakan oleh Stasiun Klimatologi BMKG di setiap kota atau kabupaten yang ada di Kalimantan khususnya.

\section{B. Saran}

Berdasarkan hasil penelitian dan pengukuran, penerapan ENN memiliki tingkat akurasi yang lebih baik dalam prediksi curah hujan. Namun berapa hal perlu disampaikan untuk penerapan ENN yang lebih baik:

Data sebagai sumber masukan bagi sistem dapat lebih rinci (perhari) dan dengan jumlah lebih banyak lagi.

GA dapat memperbaiki pembobotan neural network. Walaupun demikian perlu optimasi lebih lanjut, misalnya dengan Principal Component Analysis (PCA) [15] atau pun Logika Fuzzy [16] [17], sehingga diharapkan dapat meningkatkan akurasi prediksi curah hujan.

\section{Daftar Pustaka}

[1] Handoko, Ed., Klimatologi Dasar. Jakarta: Pustaka Jaya, 1994.

[2] Zhi-liang Wang and Hui-hua Sheng, "Rainfall Prediction Using Generalized Regression Neural Network: Case study Zhengzhou," in 2010 International Conference on Computational and Information Sciences, 2010, pp. 1265-1268.

[3] Pei-Chann Chang and Yen-Wen Wang, "Using Soft Computing Methods for Time Series Forecasting," in Recent Advances in Data Mining of Enterprise Data: Algorithms and Applications, P.M. Pardalos, Ed. Singapore: World Scientific, 2007, ch. 4, pp. 189-246.

[4] Li Chungui, Xu Shu'an, and Wen Xin, "Traffic Flow forecasting Algorithm Using Simulated Annealing Genetic BP Network," in 2010 International Conference on Measuring Technology and Mechatronics Automation, 2010, pp. 1043-1046. 
[5] Ganji Huang and Lingzhi Wang, "Hybrid Neural Network Models for Hydrologic Time Series Forecasting Based on Genetic Algorithm," in 2011 Fourth International Joint Conference on Computational Sciences and Optimization, 2011, pp. 1347-1350.

[6] Kadarsah and Ahmad Sasmita, "Standardisasi Metadata Klimatologi Dalam Penelitian Perubahan Iklim Di Indonesia," in Prosiding PPI Standardisasi 2010, Banjarmasin, 2010, pp. 1-18.

[7] I.H Witten and Eibe Frank, Data Mining: Practical Machine Learning Tools and Techniques., 2005.

[8] Daniel T Larose, Discovering Knowledge in Data., 2005.

[9] Oded Maimon Lior Rokach, Data Mining and Knowledge Discovery Handbook., 2010.

[10] Sani Susanto and Dedy Suryadi, Pengantar Data Mining : Menggali Pengetahuan Dari Bongkahan Data. Yogyakarta: Andi, 2010.

[11] Suyanto, Soft Computing: Membangun Mesin Ber-IQ Tinggi. Bandung, Jawa Barat, Indonesia: Informatika, 2008.

[12] Suyanto, Evolutionary Computing: Komputasi Berbasis 'Evolusi' dan 'Genetika'. Bandung: Informatika, 2008.

[13] Philip J. Ross, Taguchi Techniques For Quality Engineering: Loss Function, Orthogonal Experiments, Parameters and Tolerance Design, 2nd ed. New York: Mc Graw-Hill Companies, Inc., 1996.

[14] Pei-Chann Chang, Yen-Wen Wang, and C.Y. Tsai, "Evolving Neural Network for Printed Circuit Board Sales, " Expert System Application, vol. 29(1), pp. 83-92, 2005.

[15] Gao Guorong and Liu Yanping, "Traffic Flow Forecasting based on PCA and Wavelet Neural Network," in 2010 International Conference of Information Science and Management Engineering, 2010, pp. 158-161.

[16] QianZhang and Tongna Liu, "A Fuzzy Rules and Wavelet Neural Network Method for Mid-long-term Electric Load Forecasting," in Second International Conference on Computer and Network Technology, 2010, pp. 442-446.

[17] Hai-shuang Guan, Wen-ge Ma, and Qiu-ping Wang, "Real-time Optimal Control of Traffic Flow Based on Fuzzy Wavelet Neural Networks," in Fourth International Conference on Natural Computation, 2008, pp. 509-511.

[18] Wint Thida Zaw and Thinn Thu Naing, "Modeling of Rainfall Prediction over Myanmar Using Polynomial Regression," in 2009 International Conference on Computer Engineering and Technology, 2009, pp. 316-320. 